\title{
PENGEMBANGAN BUKU CERITA TEMATIK SEBAGAI MEDIA PEMBELAJARAN PENGENALAN MEMBACA \\ PADA ANAK PRASEKOLAH
}

\author{
Rita Eka Izzaty, Nur Cholimah, Rina Wulandari \\ rita_eka@uny.ac.id, nurcholimah@uny.ac.id,rina_wulandari@uny.ac.id \\ Fakultas Ilmu Pendidikan \\ Universitas Negeri Yogyakarta
}

\begin{abstract}
Abstrak
Penelitian ini dilatarbelakangi hasil observasi dan wawancara dengan pendidik tentang adanya fenomena pengenalan membaca dengan metode yang tidak sesuai dengan perkembangan anak di Taman Kanak-kanak sehingga diasumsikan menjadi hambatan dalam motivasi anak membaca pada tahap selanjutnya. Oleh karena itu, penelitian ini bertujuan untuk mengembangkan buku cerita yang sesuai dengan kondisi psikologis anak sebagai media pembelajaran pengenalan membaca di Taman Kanak-kanak.

Penelitian ini menggunakan model penelitian dan pengembangan. Tahapan yang digunakan dalam pengembangan produk adalah melakukan studi pendahuluan dengan mengkaji literatur tentang berbagai tema yang ada dalam program kegiatan belajar di TK serta mengobservasi pembelajaran pengenalan membaca yang sudah dilakukan, merumuskan berbagai aspek penting dalam buku bacaan tematik yang disesuaikan dengan perkembangan anak, dan menyusun serta menvalidasi buku dengan uji ahli, uji keterbacaan dari pengguna yaitu pendidik anak prasekolah. Analisis data yang digunakan adalah analisis deskriptif kualitatif dari hasil observasi terhadap respon anak ketika draft buku bacaan digunakan oleh para pendidik. Adapun langkah-langkahnya adalah:mengumpulkan seluruh hasil pengamatan, melakukan analisis untuk menentukan tema yang menajdi dasar pembuatan buku bacaan serta untuk menentukan isi dan format yang disesuaikan dengan perkembangan anak usia 5-6 tahun, melakukan sintesis, yaitu mengolah keseluruhan data, pembuatan simpulan terakhir yang menjadi dasar pembuatan buku bacaan.

Pada penelitian ini produk yang dikeluarkan berupa buku bacaan tematik yang dapat digunakan pendidik TK dalam mengenalkan membaca pada anak Taman Kanak-kanak.Buku tersebut minimal dilihat dari dua indikator, yaitu; Pertama, kriteria pembelajaran (instructional criteria) dan kriteria penampilan (presentation criteria), berupa gambar dan format buku.yang disesuaikan dengan perkembangan anak usia 5-6 tahun. Kriteria ini dilihat melalui uji ahli media. Kedua, buku dilihat dari hasil uji keterbacaan para pengguna, dalam hal ini akan dilakukan oleh 10 orang pendidik Kelompok Bermain dan Taman Kanak-kanak.Adapun saran terhadap produk yang dihasilkan adalah disarankan untuk diujicobakan secara empirik pada anak-anak, apakah produk ini dapat meningkatkan kemampuan pengenalan huruf dan meningkatkan motivasi membaca pada anak.
\end{abstract}

Kata kunci: Buku cerita tematik, media pembelajaran, minat membaca, anak prasekolah

\footnotetext{
Abstract

The research has the background of observation and interview result to some educators about the phenomena upon reading initiation using a method which is irrelevant to kindergarten students' development therefore assumed to be an obstacle in motivating students in the next reading stage. Therefore, the research is aimed to develop story book which is relevant to students' psychological state as the learning media to initiate reading in kindergarten.
} 
The research used research and development model. Procedures in the research were conducting initial research through literature study about various themes in kindergarten learning program and observing the learning process of initiating reading carried out so far, formulating several important aspects in thematic story book adjusted to the students' developmental stage, then developing and validating book through expert judgment as well as readability test from users, in this case are educators of pre-school children. The data analysis technique used is the descriptive qualitative from the result of observation to the students' response when the draft of the book is used by their teachers. The steps were collecting whole observation result, performing analysis to decide themes for the fundamental of story book making along with content and format adjusted to the developmental stage of children aged 5-6 years old, performing synthesis or processing the whole data, and deciding final conclusion as the fundamental basis of the book.

Product in the research is in the form of thematic story book which can be used by educators to initiate reading to kindergarten students. The book is relevant for at least two indicators. Firstly, the instructional criteria and presentation criteria in the form of pictures and book format which are adjusted for the development of students aged 5-6 years old. The criteria can be seen from media expert judgment. The second is from the result of users' readability test done by 10 educators of play group and kindergarten. Recommendation to the product is to test the product empirically to the students to prove whether it is able to increase their skill in recognizing alphabets and increase their motivation in reading.

Keywords: thematic story book, learning media, reading interest, pre-school student

\section{Pendahuluan}

Aktivitas membaca membutuhkan motivasi yang kuat. Motivasi yang kuat inilah yang membentuk keterikatan diri individu dengan aktivitas membaca di masa selanjutnya (Pecjak \& Kosir, 2008). Secara konsep, motivasi untuk membaca diartikan sebagai gabungan dari aktivitas aspek yang ada pada diri manusia yang mengarahkan perilaku dalam membentuk satu kebiasaan membaca. Hal ini merupakan satu bentuk kontinyuitas dari hasil pengalaman belajar yang diperoleh individu pada tahapan sebelumnya.

Salah satu kerangka teoretis yang digunakan untuk menjelaskan betapa pentingnya peran motivasi dalam melakukan aktivitas membaca adalah self-determination Theory yang dikemukakan oleh Deci dan Ryan (dalam (Pecjak \& Kosir, 2008). Di dalam teori tersebut dijelaskan ada 4 dimensi yang berkorelasi dengan munculnya motivasi untuk membaca pada diri individu, yaitu : kompetensi, keterkaitan, otonomi, dan ketertarikan. Selanjutnya keempat dimensi ini dianalisis dengan rinci oleh
Wigfield dan Gutrie pada tahun 1997 menjadi 3 hal besar, yaitu kompetensi dan self-efficacy beliefs, tujuan membaca, dan tujuan sosial dari membaca.

Kompetensi dan self-efficacy beliefs diartikan sebagai kepercayaan individu untuk dapat membaca dengan baik ketika ada bacaan yang menantang untuk diketahui ataupun bacaan yang dianggap sulit untuk dipahami. Studi Guthrie dan Knowles (2001) bahwa peserta didik atau individu yang merasa dirinya dapat membaca dengan baik akan memiliki motivisi intrinsik yang kuat dan kecemasan yang rendah ketika menghadapi situasi $t$ diminta untuk membaca. Namun ketertarikan dan kegunaan bahan bacaan bagi diri individu menjadi dua hal yang dipentingkan.

Hal yang kedua adalah tujuan dari peserta didik untuk membaca sesuatu. Hal ini terkait dengan dua hal, motivasi intrinsik dan ekstrinsik. Motivasi intrinsik meliputi keingintahuan, keterlibatan, dan kepentingan, sedangkan motivasi ekstrinsik lebih terarah pada pengakuan, kenaikan tingkat, ataupun kompetisi. Bagi peserta 
didik yang cenderung memiliki motivasi intrinsik, dia akan menikmati ketika membaca dan selanjutnya dapat menjadi kebiasaan yang akan dibawa sepanjang kehidupannya. Sementara yang didorong motivasi ekstrinsik ketika membaca, peserta didik sangat berkaitan dengan performance dalam membaca. Kedua motivasi ini dianggap memiliki arti penting dalam menumbuhkan perilaku gemar membaca, walau sebagai ahli juga tetap mengungkapkan bahwa faktor intrinsik diyakini memiliki daya dorong yang kuat dibanding motivasi ekstrinsik.

Hal yang ketiga, adalah tujuan sosial atau alasan sosial untuk membaca. Dalam hal ini membaca dikatakan sebagai aktivitas sosial yang dilakukan di dalam kelas. Pemahaman bacaan bersama dapat menjadi efek penting bagi kehidupan peserta didik, yang selanjutnya dapat disosialisasikan pemahaman tersebut ke lingkungan sosialnya.

Selain hal yang telah dijelaskan, di dalam dunia pendidikan ditemukan hasil penelitian yang menunjukkan bahwa guru atau pendidik seringkali menggunakan cara atau metode yang merendahkan daya untuk membaca bagi peserta didik. Cara yang salah, ketidakmampuan untuk menjaga motivasi intrinsik dan tidak mendorong keingintahuan lebih lanjut pada peserta didik menjadi permasalahan yang serius pada dunia pendidikan (Pecjak \& Kosir, 2008). Beranjak dari sini pula, maka muncullah pertanyaan, "Bagaimana cara untuk menumbuhkan dan mempertahankan membaca para peserta didik dalam kegiatan belajar di sekolah?" Salah satu cara yang ditekankan oleh beberapa peneliti (Covington, 2000; Sweet \& Guthrie, 1998) adalah meningkatkan kesenangan membaca dengan cara pendidik memberikan metode yang bervariasi, menyediakan berbagai macam buku bacaan sebagai media pembelajaran yang ketika akan dipakai peserta didik diminta untuk memilih sendiri. Terkait dengan buku bacaan, Edmunds dan Bauserman (2006) menyatakan bahwa berdasarkan hasil kajiannya, salah satu faktor yang mempengaruhi meningkatnya minat membaca pada diri anak-anak adalah karakteristik dari buku. Pada anak-anak prasekolah, anak sangat menikmati ceritacerita yang lucu atau menakutkan dengan ilustrasi yang bagus. Dari cerita lucu, membuat mereka senang dan tertawa bebas, sementara cerita-cerita yang menakutkan akan membuatnya penasaran dengan apa yang akan terjadi selanjutnya.Hasil penelitian Edmuns dan Bauserman (2006) tersebut merekomendasikan beberapa hal yang perlu diperhatikan pendidik dalam membelajarkan membaca agar dapat meningkatkan keinginan untuk selalu membaca, yaitu:

Pertama, memilih buku sendiri, salah satu cara untuk meningkatkan membaca pada anak-anak adalah dengan membiarkan anak-anak untuk emmilih sendiri buku yang dikehendakinya. Oleh karena itu, sekolah diharapkan dapat menyediakan berbagai macam sumber buku yang terkait dengan tema-tema pembelajaran dalam berbagai bentuk penyajian. Selanjutnya anak dapat diminta untuk menceritakan kembali isi buku bacaannya.Kedua, memilah jenis-jenis buku. Hal ini dapat membantu anak untuk mendapatkan buku yang diinginkannya. Dalam hal ini pemberian nama atau label pada tempat buku menjadi hal yang sebaiknya dilakukan.Ketiga, memperhatikan ketertarikan untuk tema-tema buku. Selain berdasarkan program kegiatan belajar, anak dapat ditanya tentang tema yang dinginkannya. Keempat, kemudahan akses dalam mendapatkan buku. Hal yang perlu diperhatikan adalah letak perpustakaan ataupun bila diletakkan di dalam kelas adalah kemudahan anak untuk menjangkaunya.Kelima, keaktifan dengan orang lain terkait dengan buku bacaannya. Dalam hal ini, menjadikan anak untuk berbagi dengan orang lain dan menimbulkan semangat untuk menceritakan buku yang disukainya.

Usia anak-anak awal (0-6 tahun ) merupakan usia emas. Pada masa ini anak tumbuh dan berkembang secara cepat. Di 
Indonesia saat ini, lembaga-lembaga pendidikan pra-sekolah menawarkan alternatif kegiatan untuk menarik perhatian dan minat orang tua dan anak. Sebagai suatu lembaga, harusnya institusi tersebut, dalam hal ini adalah play-group dan TK, selalu berusaha meningkatkan mutu pembelajarannya. Peningkatan mutu institusi pendidikan pra-sekolah dapat dicapai dengan berbagai cara. Dua hal penunjang program kegiatan belajar adalah kualitas tenaga kependidikan sebagai perangkat utama yang memutar jalannya roda institusi sertasistem atau program kegiatan pembelajaran yang berpihak pada anak. Kedua hal ini akan berimbas pada peningkatan kualitas hasil pembelajaran melalui ketepatan dalam penyusunan dan metode penyampaian materi yang tertuang dalam satuan program kegiatan.

Institusi pendidikan anak usia dini saat ini cukup banyak dan memiliki beragam metode pendekatan. Ada institusi yang mampu menjalankan visi dan misinya, yakni menyatukan penghargaan dunia anak dan konsep-konsep pembelajaran sehingga orang tua merasa puas. Institusi yang demikian, mampu mengakomodasi dan mewadai potensi anak secara proporsional. Meskipun demikian, sebagian besar institusi pendidikan untuk anak usia pra-sekolah belum mampu mewujudkan produk program pembelajaran yang baik.

Fenomena yang terjadi sekarang adalah banyak tenaga pendidik yang mengharapkan homogenitas pada anak didiknya dalam banyak hal. Mereka nyaris tidak berbesar hati untuk melihat perbedaan cara belajar anak didiknya dan memperlakukan mereka seakan-akan anak adalah makhluk kecil yang memiliki pola yang sama. Dari tinjauan psikologi, pengharapan-pengharapan dan perlakuan orang dewasa dalam proses pembelajaran dalam rangka mendidik dan mengasuh yang tidak sesuai dengan potensi anak justru akan memperburuk prestasi berikutnya.

Setiap anak sebenarnya memiliki cara yang berbeda untuk menjadi pandai. Ada anak yang menjadi pandai melalui kata- kata, namun ada pula yang melalui angkaangka dan logika, gambar dan warna, musik dan ritmik, ekspresi fisik dan gerak, dan interaksi sosial. Bahkan ada anak yang belajar menjadi pandai melalui pengalaman belajar dalam alam dan ada pula yang menjadi pandai berdasarkan pemahaman mereka terhadap diri sendiri.

Secara umum faktor -faktor yang dapat menunjang pemenuhan kebutuhan dasar anak untuk tumbuh kembang adalah adanya:

a. Stimulasi. Hal ini merupakan faktor yang penting dalam menunjang perkembangan individu. Individu yang mendapat stimulasi atau rangsangan yang terarah dan teratur akan lebih cepat mempelajari sesuatu karena lebih cepat berkembang dibandingkan individu yang tidak mendapatkan banyak stimulasi Individu akan berkembang pola-pola berfikir, merasakan sesuatu, dan bertingkah laku, bila banyak diberi rangsangan yang berupa dorongan dan kesempatan dari lingkungan disekitarnya. Walaupun mungkin ada individu yang berbakat, namun bila lingkungannya tidak mendukung, potensinya untuk berkembangpun dapat terhambat. Sebaliknya, bila ada individu yang belum terlihat potensi pada dirinya, namun rangsangan dan kesempatan bereksplorasi diberikan secara maksimal dan sesuai dengan kebutuhan usianya, maka individu tersebut dapat berkembang jauh lebih baik. Sebagai contoh, individu yang sejak dini diajarkan bagaimana memecahkan permasalahannya akan lebih mudah menyelesaikan masalah lain karena adanya pengalaman belajar. Misalnya, individu yang sedang bermain bola kemudian bolanya masuk ke bawah meja. Hal yang dapat kita lakukan adalah tidak mengambilkan bola tersebut tetapi mengajarkan bagaimana mengambil bola dengan menggunakan alat bantu seperti tongkat. Dengan begitu, individu akan memahami salah 
satu strategi pemecahan masalah dengan memahami bagaimana caranya mengambil bola yang ada di bawah meja. Proses belajar dari pengalaman ini akan memberikan pemahaman kepada individu bagaimana memecahkan masalah yang serupa nantinya.

b. Motivasi dalam mempelajari sesuatu. Dalam hal ini, dua pihak yang berperan penting adalah orangtua dan pendidik. Motivasi yang ditimbulkan dari sejak usia awal akan memberikan hasil yang berbeda pada individu dalam menguasai sesuatu. Dorongan yang bersifat membangun daya fikir dan daya cipta individu, akan membuat individu termotivasi untuk melakukan yang lebih baik lagi. Pemberian kesempatan pada anakpun dalam mengeksplorasi sesuatu merupakan salah satu cara dalam memotivasi individu belajar. Hal ini dapat dilakukan oleh pihak institusi pendidikan prasekolah maupun dari pihak keluarga. Anak dimotivasi untuk menjelajah, meneliti, berkarya atau memegang sesuatu utnuk memuaskan rasa ingin tahunya merupakan hal yang dibutuhkan anak pada usia ini. Bila terlihat hal yang dilakukannya mengandung unsur bahaya, hal yang dapat dilakukan adalah memberi pengertian namun bukan untuk melarang atau menghapuskan rasa ingin tahunya dengan kemarahan. Penerapan yang ada di institusi prasekolah contohnya, dengan adanya berbagai macam area bermain dan belajar akan memberi kesempatan kepada individu untuk mencoba berbagai macam hal. Dalam pemberian kesempatan kepada individu, metode yang digunakan pendidik hendaknya jangan memaksa mengingat keinginan individu yang berbeda-beda walaupun stimulasi yang ada adalah sama. Misalnya pada area bermain olah fisik, individu diminta untuk bermain dengan bola. Semua individu diharuskan melakukan hal yang sama yaitu menendang bola dan di luar itu individu dilarang

melakukannya.

Terkait dengan penjelasan sebelumnya tentang perlunya memahami berbagai hal pada anak prasekolah, Miller (2003) mengatakan bahwa ada sejumlah faktor perkembangan sebagai ciri khas anak prasekolah yang dapat mempengaruhi perilaku atau respon yang diberikannya terhadap sesuatu. Salah satu faktor yang menonjol adalah sifat egosentris. Istilah egosentrisme ini bukanlah mempunyai makna yang sama konotasinya dengan orang dewasa yang berarti ingin selalu berpusat pada dirinya dan tidak mempertimbangkan sesuatu di luar dirinya. Pada anak-anak, egosentris merupakan proses perkembangan yang normal dan dapat dimengerti. Pada kenyataannya, mereka hanya berpikir bahwa orang lain melakukan sesuatu seperti apa yang dipersepsikannya. Sebagai akibatnya, pada anak prasekolah sering terlihat sifat kurang sabar dan menginginkan apa yang diinginkannya segera diraih, dengan berbagai cara yang menarik perhatian lingkungan sekitarnya (Saifer, 2003).

Lebih lanjut, Saifer (2003) mengatakan bahwa pada umumnya faktorfaktor perkembangan yang mempengaruhi perkembangan anak usia prasekolah adalah :

a. Anak-anak masih sulit untuk dapat berpikir bahwa seseorang mempunyai kejelekan dan kebaikan, atau dengan kata lain bahwa seseorang itu hanya baik semua atau tidak baik semua. Mereka hanya berpikir, "semua atau tidak sama sekali”.

b. Fokus dari berpikir dan perhatian anak-anak adalah kejadian masa ini. Seringkali ada kata-kata yang menunjukkan tentang cita-cita, misalnya " aku besok ingin jadi dokter", namun makna atau konsep sebenarnya mereka belum mengerti. Begitu juga berpikir tentang suatu kejadian saat ini dapat mengikuti suatu kejadian di masa datang masih sulit. 
c. Fokus pada respon yang terlihat dan harus segera. Anak merespon sesuatu berdasarkan pengertian dirinya sendiri. Mereka menganggap bahwa orang akan berpikir sama seperti yang dipikirkan olehnya. Anak-anak belum terfokus pada sesuatu yang nyata atau tampak. Anak usia ini pula bila menginginkan sesuatu, maka harus segera terpenuhi, bila tidak seringkali ia menunjukkan perilaku yang negatif, seperti tindakan agresif.

d. Berpikir imajinatif. Salah satu ciri masa ini adalah masa yang penuh fantasi. Sulit bagi anak-anak untuk membedakan mana fantasi dan mana yang realita.

e. Perbedaan temperamen.

Temperamen merupakan gaya perilaku seseorang dalam merespon sesuatu. Temperamen atau watak dasar anak inilah yang mempengaruhi bagaimana mereka menyesuaikan diri di berbagai situasi.

f. Bergantung.Pada usia ini anak masih cenderung memiliki sifat ketergantungan terhadap orang lain, sehingga harapan akan mendapat perlindungan dan kasih sayang sangatlah besar. Namun, bila hal ini mereka rasa tidak mendapatkannya, maka reaksi-reaksi yang muncul seperti mengamuk, menangis, atau munculnya tindakan yang melanggar aturan-aturan disekitarnya.

Mueller (2005) menyatakan bahwa melalui buku, anak mempelajari aturan bahasa tulis yang meliputi :

1. Mengenal bagian depan dan bagian belakang dari sebuah buku

2. Mengikuti tulisan dari kiri ke kanan, dan atas ke bawah pada sebuah halaman

3. Membedakan makna tulisan gambar yang terkait dengan lingkungannya

4. Mengikuti tulisan saat dibacakan

5. Membedakan atara huruf dan kata
6. Mengetahui bahwa kalimat tersusun dari kata-kata yang terpisah

7. Memahami bahwa cetakan dan tulisan membawa pesan tertentu dengan mengenali label, dan bentuk tertulis lainnya

Selain itu, manfaat yang diperoleh anak ketika mendapatkan situasi yang menyenangkan untuk belajar membaca, maka anak dapat mendengarkan untuk mendapatkan informasi, mengungkapkan gagasan, berbagi cerita, dan pendapat, anak dapat menunjukkan kemampuan untuk mengaplikasikan suara pada simbol abjad, termasuk mengenal huruf alfabet, mengenali nama dan tulisan, serta bunyinya, serta anak dapat mengembangkan kemampuan untuk mendengar, mengenal, dan mengubah satuan bunyi terkecil (fonem) dalam ucapan, suku kata, rima kata, dan bunyi awal.

Dari berbagai kajian literatur, aktivitas membaca membutuhkan motivasi yang kuat pada diri individu, baik yang bersifat intrinsik meupun ekstrinsik. Namun, untuk menjadikan aktivitas membaca menjadi suatu kebiasaan yang melekat pada diri seseorang, tentu saja memerlukan pembiasaan dari masa sebelumnya.

Sebagai masa emas, usia dini merupakan masa yang tepat untuk dikenalkan untuk membaca. Dalam hal ini bukan berarti anak usia dini sudah diharapkan untuk membaca dengan lancar, namun lebih ditekankan pada proses pendidikan di lembaga prasekolah yang dapat membuatnya terkesan dan menyenangi buku bacaan. Pada proses perkembangan manusia, apa yang didapat dari pengalaman belajar sebelumnya akan membentuk kesan yang akan dibawa ke masa selanjutnya. Oleh karena itu, lembaga pendidikan prasekolah sebagai gerbang awal untuk mempelajari banyak hal diharapkan memberikan pengalaman belajar yang sesuai dengan perkembangan diri anak sehingga dapat ditangkap dan diapresiasi dengan baik.

Selain memperhatikan berbagai aspek yang dapat menumbuhkan motivasi anak dalam membaca, seperti kompetensi dan self efficacy beliefs, penanaman motivasi 
intrinsik, serta mempertimbangkan tujuan sosialnya, penelitian ini menekankan untuk mengembangkan buku bacaan tematik sebagai media yang dapat digunakan pendidik ketika mengenalkan aktivitas memabca pada anak prasekolah. Seperti yang telah diuraikan pada kajian pustaka, karakteristik buku bacaan yang tepat dengan perkembangan anak haruslah diperhatikan, baik isi, ilustrasi yang digunakan, juga format buku.

Sejalan dengan aspek perkembangan kognitif anak prasekolah yang masih sederhana, bahasa yang digunakan pada buku bacaan bersifat sederhana dan dapat dimengerti oleh anak dengan jalan cerita yang membuat anak senang ataupun membuatnya penasaran dengan apa yang akan terjadi kemudian. Buku bacaan yang bersifat tematik ini diharapkan dapat menjadi buku contoh sebagai media pembelajaran yang dapat digunakan pendidik dalam menjalankan program kegiatan belajar sehari-hari. Di sisi anak prasekolah, dengan adanya buku bacaan tesebut menjadi dukungan pemberian pengalaman belajar positif, khususnya membentuk kegemaran membaca.

\section{METODE PENELITIAN}

Penelitian ini menggunakan model penelitian dan pengembangan. Hal ini dikarenakan penelitian ini akan menghasilkan produk baru untuk dikembangkan.Lokasi penelitian ini di TK Rumahku Tumbuh di Sleman, Yogyakarta.

Pada observasi awal, ada 2 guru yang diobervasi ketika melakukan pembelajaran dan 4 anak diwawancara mengenai karakteristik buku cerita yang disukainya.

Prosedur penelitian dan pengembangan ini menggunakan tiga dari empat tahap yang dikemukan Thiagarajan (dalam Arifin, 2011) yang akan dijelaskan pada bagan 2 . berikut ini.

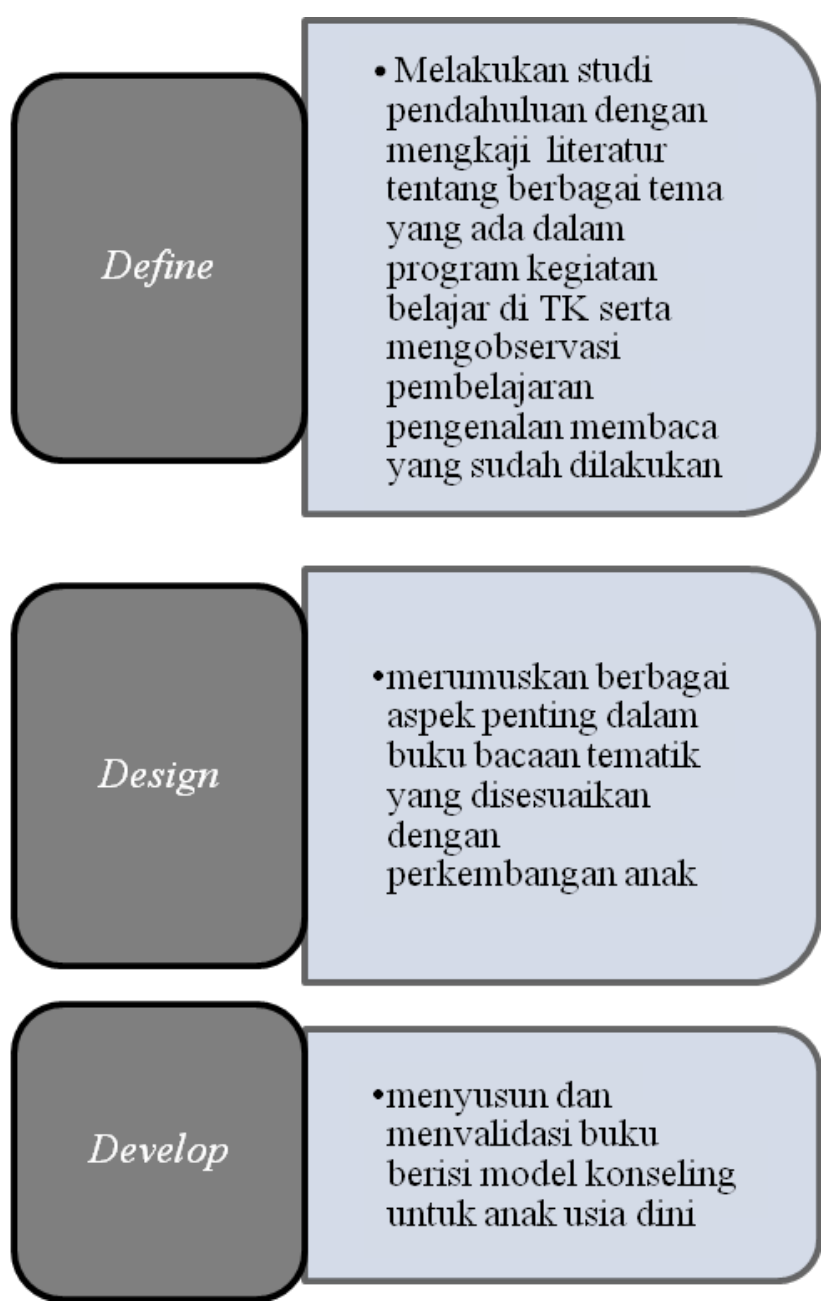

\section{Bagan 1. Prosedur Penelitian}

Data yang dikumpulkan berupa data kualitatif. Oleh karena itu, instrumen utama dalam penelitian ini adalah tim peneliti sendiri (Putra, 2012). Data terutama didapatkan dari hasil observasi. Untuk menjaga keobjektifan dilakukan pengamatan oleh dua orang dengan beberapa kali observasi.

Analisis data yang digunakan adalah analisis deskriptif kualitatif dari hasil observasi terhadap respon anak ketika draft buku bacaan digunakan oleh para pendidik. Adapun langkah-langkahnya adalah :

1. Mengumpulkan seluruh hasil pengamatan.

2. Melakukan analisis untuk menentukan tema yang menajdi dasar pembuatan buku bacaan serta untuk menentukan isi dan format yang disesuaikan dengan perkembangan anak usia 5-6 tahun. 
3. Melakukan sintesis, yaitu mengolah keseluruhan data

4. Pembuatan simpulan terakhir yang menjadi dasar pembuatan buku bacaan.

Pada penelitian ini produk yang dikeluarkan berupa draft buku bacaan tematik yang dapat digunakan pendidik TK dalam mengenalkan aktivtas membaca pada anak Taman Kanak-kanak.Draft buku tersebut minimal dilihat dari dua indikator, yaitu; Pertama, kriteria pembelajaran (instructional criteria) dan kriteria penampilan (presentation criteria), berupa gambar dan format buku.yang disesuaikan dengan perkembangan anak usia 4-5 tahun. Kriteria ini dilihat melalui uji ahli media. Kedua, draft buku akan dilihat dari hasil uji keterbacaan para pengguna, dalam hal ini akan dilakukan oleh 10 orang pendidik Kelompok Bermain dan Taman Kanakkanak.

\section{HASIL DAN PEMBAHASAN}

\section{Tahap 1 (asesmen awal)}

Penelitian dimulai sejak bulan Juni 2014. Setelah berkoordinasi, tim peneliti yang dibantu mahasiswa melakukan observasi awal di dalam kelas ketika pembelajaran pengenalan membaca dilakukan. Seiring observasi terhadap guru dilakukan, wawancara terhadap anak sebagai asesmen awal pendapat anak mengenai karakteristik buku yang disukainya.

Secara garis besar hasil observasi awal didapatkan hasil bahwa pengenalan membaca pada lokasi penelitian salah satu caranya dilakukan dengan metode bercerita. Dalam bercerita, guru menggunakan metode buku. Buku-buku yang digunakan sebagian besar tidak sesuai dengan tema yang ada dalam program kegiatan belajar saat itu. Karakteristik buku yang digunakan masih terlalu banyak kata dan berukuran kecil, namun untuk warna sudah digunakan dengan tekstur kertas yang baik atau tidak mudah robek.

Berdasarkan wawancara dengan anak diketahui bahwa anak menyukai gambar hewan, kartun, dan tokoh-tokoh animasi dan superhero. Anak-anak juga menyatakan bahwa mereka suka dengan buku-buku yang besar, berwarna warni dengan bentuk buku yang bermacam-macam, seperti persegi, kotak dengan gambar yang banyak.

\section{Tahap 2 (workshop pembuatan buku cerita)}

Pembuatan buku cerita disesuaikan dengan tema-tema pada program kegiatan. Adapun peserta workshop adalah guru-guru dan peneliti berjumlah 7 orang. Workshop ini menghasilkan draft produk awal, berupa buku cerita bergambar yang isinya disesuaikan dengan tema yang ada di Taman Kanak-kanak. Dari 11 tema yang ada, yang dijadikan tema buku cerita adalah : diri sendiri, alam semesta, alat komunikasi, macam-macam pekerjaan, lingkunganku, dan binatang.

\section{Tahap 3 (Uji Ahli Media)}

Dalam hal ini ahli yang akan melakukan validasi adalah 1 orang ahli dari media pembelajaran anak usia dini. Adapun komponenm untuk uji ahli media adalah : Desain cover, tata letak (teks dan gambar), kemenarikan pilihan warna untuk anak prasekolah, kesesuaian pilihan huruf, ukuran huruf, ketebalan kertas, pilihan tokoh cerita, kesesuaian media dengan tujuan pembelajaran, kemudahan penggunaan media, dan ketepatan penggunaan bahasa. Berikut dipaparkan hasil prosentase uji validasi ahli media pada masing-masing tema.

\section{Tabel 1. Hasil Uji Ahli}

\begin{tabular}{|c|c|}
\hline $\begin{array}{c}\text { Tema/ } \\
\text { Prosentase } \\
\text { penilaian } \\
\text { produk }\end{array}$ & Saran \\
\hline $\begin{array}{l}\text { ALAM } \\
\text { SEMESTA } \\
93 \%\end{array}$ & $\begin{array}{l}\text { 1. Background warnanya agak gelap, kurang } \\
\text { menceriakan, kurang membawa aura ceria, } \\
\text { walaupun tema/ materi berhubungan } \\
\text { dengan siang-malam perlu dipilih warna } \\
\text { yang agak ceria. Mungkin warna-warna } \\
\text { dark blue lebih pas. } \\
\text { 2. Lubang untuk kaitan antar kertas terlalu } \\
\text { minggir sehingga rawan untuk sobek atau } \\
\text { kertas jadi tercerai/ lepas dari kaitan. } \\
\text { tapi akan lebih baik pasa untuk ukuran } \\
\text { tangan anak bila ukuran kertas diperkecil }\end{array}$ \\
\hline
\end{tabular}




\begin{tabular}{|c|c|}
\hline & $\begin{array}{l}\text { sedikit. Setidaknya seperlunya anak besar/ } \\
\text { lebarnya. } \\
\text { 4. warna latar/ background perlu dipilih yang } \\
\text { agak cerah. Kaitan buku perlu dibuat yang } \\
\text { kuat. }\end{array}$ \\
\hline $\begin{array}{l}\text { PEKERJAAN } \\
100 \%\end{array}$ & 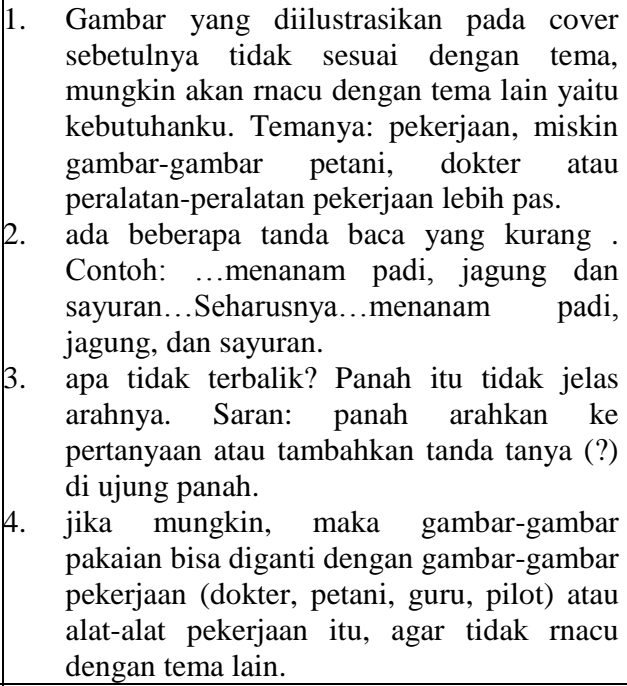 \\
\hline $\begin{array}{l}\text { DIRI } \\
\text { SENDIRI } \\
100 \%\end{array}$ & $\begin{array}{l}\text { 1. Pada materi tentang KEPALA, tentang } \\
\text { "rambut" dan "alis" perlu juga diberikan } \\
\text { materi tentang manfaatnya, seperti anggota } \\
\text { tubuh yang ada. } \\
\text { 2. Perlu dibuat yang kuat. } \\
\text { 3. } \\
\text { background kalau bisa diganti yang tidak } \\
\text { lurik-lurik yang dapat melelahkan mata } \\
\text { anak. Kaitan buku perlu dibuat yang kuat. }\end{array}$ \\
\hline $\begin{array}{l}\text { KOMUNIKA } \\
\text { SI } \\
97 \%\end{array}$ & $\begin{array}{l}\text { 1. Warna-warna cover cerah. Jika mungkin, } \\
\text { cover disertai gambar-gambar yang } \\
\text { merepresentasikan alat-alat komunikasi } \\
\text { yang dipelajari/ diajarkan. } \\
\text { 2. Halaman-halaman huruf terlalu padat/ } \\
\text { banyak. } \\
\text { 3erlalu banyak pesan dan terlalu/ agak } \\
\text { tinggi untuk anak usia 4-6 tahun. } \\
\text { 4. Warna-warna huruf di halaman } 2 \text { sebaiknya } \\
\text { diganti warna yang lebih cerah. Halaman 5 } \\
\text { "pendengar" ganti dengan "pemirsa". }\end{array}$ \\
\hline $\begin{array}{l}\text { DIDI } \\
\text { SAYANG } \\
\text { BINATANG } \\
\text { (TEMA: } \\
\text { BINATANG) } \\
93 \%\end{array}$ & $\begin{array}{l}\text { 1. Teks di halaman } 1 \text { Desa seharusnya huruf } \\
\text { kecil. Teks bunyi ayam berkokok (halaman } \\
\text { 1) kukuruyuk ganti dengan kukuruyuk. } \\
\text { Begitu juga dengan halaman } 2 \text { meong, } \\
\text { kwek, dan cuit meong...kwek-kwek...cuit- } \\
\text { cuit... Halaman } 6 \text { Kalimat kurang lengkap. } \\
\text { Seharusnya Didi senang. Halaman 7, } \\
\text { sebelum berangkat ke sekolah Disi } \\
\text { memberi/ mengucapkan salam ayah dan ibu. } \\
\text { Halaman } 7 \text { orangtua Disi= ayah dan ibu. } \\
\text { 2. Kurang tebal untuk ukuran buku sebesar itu. } \\
\text { 3. Cek catatan untuk item } 2 . \\
\text { 4. Kertas perlu dipilih yang lebih kecil, tebal } \\
\text { untuk ukuran buku cerita sebesar ini dan } \\
\text { gambar-gambar yang cukup besar untuk } \\
\text { anak TK. Tata tulis, tanda baca perlu }\end{array}$ \\
\hline
\end{tabular}

Berdasarkan uji validasi ahli media, secara garis besar akan dilakukan perbaikan draft buku dengan memperhatikan; a. Warna latar/ background perlu dipilih yang agak cerah. Kaitan buku perlu dibuat yang kuat.

b. Gambar-gambar pakaian bisa diganti dengan gambar-gambar pekerjaan (dokter, petani, guru, pilot) atau alat-alat pekerjaan itu, agar tidak rancu dengan tema lain.

c. background kalau bisa diganti yang tidak lurik-lurik yang dapat melelahkan mata anak. Kaitan buku perlu dibuat yang kuat.

d. Warna-warna huruf di halaman 2 sebaiknya diganti warna yang lebih cerah. Halaman 5 "pendengar" ganti dengan "pemirsa".

e. Kertas perlu dipilih yang lebih kecil, tebal untuk ukuran buku cerita sebesar ini dan gambar-gambar yang cukup besar untuk anak TK. Tata tulis, tanda baca perlu dibetulkan sesuai pengucapannya.

\section{Tahap 4 (Uji keterbacaan dari pengguna)}

Uji coba di lapangan terkait penelitian ini telah ditempuh dengan mengambil 10 guru untuk mencermati/ memvalidasi keterbacaan dengan indikator sebagai berikut:

a. Paragraph

1) Jumlah paragraph

Keterangan:

Paragraph adalah bagian bab dalam suatu karangan yang biasanya mengandung satu ide pokok dan penulisannya dimulai dengan garis baru, alinea.

2) Jumlah kalimat per paragraph Keterangan:

Kalimat adalah kesatuan perkataan lisan yang mengungkapkan suatu konsep pikiran.

b. Kalimat

1) Panjang kalimat (rerata jumlah kata per kalimat)

Keterangan;

Kata adalah morfem atau kesatuan morfem sebagai satuan terkecil, misal: batu, pejuang.

2) Kalimat majemuk Keterangan: 
Kalimat majemuk adalah gabungan dua klausa atau lebih.

Klausa adalah kelompok kata yang minimal terdapat subjek dan predikat.

3) Kalimat pasif

Keterangan:

Kalimat pasif adalah kalimat yang subjeknya merupakan tujuan dari perbuatan predikat.

4) Kalimat berpolisemi

Keterangan:

Kalimat polisemi adalah bentuk bahasa (kata, frasa) yang mempunyai makna lebih dari satu.

c. Kata

1) Jumlah kata per kalimat

Kata adalah morfem atau kesatuan morfem sebagai satuan terkecil, misal: batu, pejuang.

2) Kata tak lazim

Keterangan:

Tak lazim adalah tidak biasa atau tidak umum.nn

3) Kata istilah

Keterangan:

Kata atau gabungan kata yang bermakna dalam bidang tertentu.

4) Kata serapan

Keterangan:

Kata serapan adalah kata yang diambil dari bahasa asing.

5) Kata penghubung

6) Kata majemuk

Keterangan:

Kata majemuk adalah gabungan morfem dasar.

Morfem adalah satuan bahasa terkecil yang bermakna.

d. Kesesuaian pilihan huruf

e. Tata letak teks/ gambar

f. Ukuran huruf

Berdasarkan indikator uji keterbacaan, maka diperoleh hasil seperti yang dijelaskan pada Tabel 2.

Tabel 2. Hasil Uji Keterbacaan

\begin{tabular}{|l|l|l|}
\hline No. & Tema & $\begin{array}{l}\text { Hasil } \\
\text { Prosentase }\end{array}$ \\
\hline 1 & Pekerjaanku & $65 \%$ \\
\hline
\end{tabular}

\begin{tabular}{|l|l|l|}
\hline 2 & Mengenal diri sendiri & $84 \%$ \\
\hline 3 & Alam semesta & $86 \%$ \\
\hline 4 & $\begin{array}{l}\text { Binatang (Sayang } \\
\text { binatang) }\end{array}$ & $87 \%$ \\
\hline 5 & Komunikasi & $66 \%$ \\
\hline
\end{tabular}

Perbaikan Berdasarkan hasil berdasarkan hasil uji keterbacaan maka berikut perbaikan hasil uji lapangan:

a. masih ada huruf yang membingungkan anak untuk memahaminya antarhuruf $\mathrm{j} / \mathrm{i}$.

b. kurang kuat, mudah lepas per halaman, ketebalannya kurang.

c. huruf $\mathrm{j}$ menjadi $\mathrm{I}$ dan $\mathrm{t}$ menjadi $\mathrm{t}$ mirip tanda plus.

Selain berdasarkan instrumen uji keterbacaan, pengguna (pendidik) memberikan pendapat seperti berikut ini yang terkait dengan draft buku bacaan.

1. Pendapat tentang buku cerita tematik

a. Membantu dalam menyampaikan pembelajaran tematik

b. Membantu dalam pemahaman ciptaan Tuhan

c. Bagus, karena dapat mengenal informasi lewat buku dan bisa dibaca sendiri atau pendidik

d. Buku ini berguna untuk pembelajaran tematik dan sesuai karakteristik anak TK

2. Pendapat tentang buku cerita tematik mendukung keaksaraan

Mendukung keaksaraan karena katakata dan kalimatnya sederhana mudah dipahami.

\section{Pendapat tentang buku cerita tematik} manfaat pada guru

a. Membantu guru dalam menyampaikan materi sehingga memudahkan guru mengenalkan aksara kepada anak

b. Menjadi alat peraga

c. Efektif dan efisien

d. Melatih guru bercerita di depan

e. Sangat membantu dalam proses tematik

f. Memudahkan bagi guru mengenalkan tentang tema anak 


\section{Pendapat tentang buku cerita tematik manfaat pada anak}

a. Anak bisa mengenal aksara melalui cerita bergambar

b. Membuat anak-anak tertarik dengan buku

c. Anak bisa mengenal aksara melalui media

d. Anak dapat membaca tulisan perkata

e. Melatih Keberanian

f. Sangat menyenangkan karena anak dapat berfantasi melalui buku tematik ini

g. Stimiulasi keaksaraan

h. Lebih Fokus

i. Mendapat banyak pengetahuan dan mendukung keaksaraan

j. Menyerap materi dengan melihat gambar dan penjelasan dari guru.

\section{Saran untuk perbaikan}

a. Judul buku komunikasi terlalu besar jika untuk sendiri tapi kalau klasikal cuku

b. Bahasa terlalu simpel

c. Buku didi sayang binatang terlalu besar

d. Gambar unuk buku berjudul tebak pekerjaan lebih prporsional

e. Tampilan gambar lebih ditingkatkan agar lebih menarik

f. Halaman diperbanyak

g. Kertas sudah bagus gambar dan warnanya sudah menarik

h. Judul Alam semesta lebih dipertajam warnanya dan penjilitan yang kurang kuat.

Tulisan di perbesar

Hasil penelitian ini berupa buku cerita tematik yang digunakan sebagai media pembelajaran aktivitas pengenalan membaca. Buku cerita tersebut dikembangkan melalui serangkaian prosedur ilmiah yang terstruktur yang dimulai dari tahap asemen awal sampai proses validasi ahli dan pengguna. Bila ditinjau dari salah satu komponen self determination theory(dalam Wigfield, Guthrie, Tonks, \& Perencevich, 2004) produk ini diasumsikan dapat memotivasi anak untuk belajar membaca dengan senang. Hal ini berdasarkan pada hasil akhir produk yang dilihat dari segi pemakaian warna, huruf yang besar seperti keinginan anak, serta tema yang digunakan yang terkait dengan program aktivitas belajar di institusi prasekolah sehari-hari. Adanya kesesuaian antara keinginan anak terhadap gambaran buku bacaan yang disukainya serta tentang gambaran kehidupan sehari-hari yang tercermin dalam buku bacaan tersebut, maka dapat diartikan pada diri anak dapat timbul motivasi instinsik yang kuat sehingga dapat mendorong keinginan untuk belajar dan mengetahui isi buku tersebut.

Terkait dengan pilihan tema, adanya buku ini dirasa pendidik ketika melakukan uji pengguna sangat berguna untuk membantu Membantu dalam menyampaikan pembelajaran tematik, Mendukung stimulasi keaksaraan karena kata-kata dan kalimatnya sederhana mudah dipahami,anak dapat membaca tulisan perkata, dan melatih keberanian dan kemandirian dalam membaca buku, serta anak dapat terletih konsentrasi ketika anak senang melihat atau membaca buku tersebut dalam rentang perhatian yang cukup lama.

Produk ini dihasilkan baru melalui uji ahli dan pengguna dan produk ini belum diujicobakan secara empirik pada anak-anak, apakah produk ini dapat meningkatkan kemampuan pengenalan huruf dan meningkatkan motivasi membaca pada anak. KESIMPULAN

Pada penelitian ini produk yang dikeluarkan berupa buku bacaan tematik yang dapat digunakan pendidik TK dalam mengenalkan membaca pada anak Taman Kanak-kanak.Buku tersebut minimal dilihat dari dua indikator, yaitu; Pertama, kriteria pembelajaran (instructional criteria) dan kriteria penampilan (presentation criteria), berupa gambar dan format buku.yang disesuaikan dengan perkembangan anak usia 4-5 tahun. Kriteria ini dilihat melalui uji ahli media. Kedua, buku dilihat dari hasil uji keterbacaan para pengguna, dalam hal ini akan dilakukan oleh 10 orang pendidik Kelompok Bermain dan Taman Kanakkanak. 
Buku cerita tematik yang dihasilkan pada penelitian ini disarankan untuk diujicobakan secara empirik pada anak-anak, apakah produk ini dapat meningkatkan kemampuan pengenalan huruf dan meningkatkan motivasi membaca pada anak.

\section{DAFTAR PUSTAKA}

Arifin, Zainal. (2011). Penelitian pendidikan: metode dan paradigma baru. Bandung: PT Remaja Rosdakarya.

Ashiabi, G.S. (2000). Promoting the emotional development of preschoolers. Early Childhood Education Journal, Vol. 28, No.2.

Bimba-aiueo. (2013).Kenapa minat membaca di Indnesia rendah? http://www.bimbaaiueo.com/kenapa-minat-baca-diindonesia-rendah/diunduh 3 April 2014.

Covington, M. V. (2000). Intrinsic versus extrinsic motivation in schools. Current Direction in Psychological Science, 9, 1, 22-25.

Edmunds, K. M., Bauserman, K. L. (2006). What teachers can learn about reading motivation through conversations with childrren. The Reading Teacher, 59,5.

Kompas. (2013). Minat membaca yang rendah. Kamis 19 Desember 2013

Miller, K. (2003). The crisis manual for early childhood teachers. USA : Gryphon House

Muller, S. (2005). Belajar membaca dengan benda-benda di Sekitar Kita untuk Anak Usia 3-8 Tahun (terjemahan). Jakarta: Erlangga

Pecjak, S., \& Kosir, K. (2008). Reading motivation and reading efficiency in third and seventh grade pupils in relation to teachers activities in the classroom. Studia Psychologia, 50, 2.
Putra, Nusa. (2012). Research and development. Jakarta: Raja Grafindo Persada.

Seifer, S. (2003). Practical solutions to practically every problem: the early childhood teacher's manual (rev-ed). United States : Readleaf Press.

Sweet, A. P., Guthrie, J.T. (1998). Teacher perception and student reading motivation. Journal of Educational Psychology, 90, 2, 210-223.

Wigfield, A., Guthrie, J., Tonks, S., \& Perencevich, K.C. (2004). Children's motivation for Reading; Domain Specificity and instructional influences. The Journal of Educational Research No. 97,6

http://poskotanews.com/2013/09/27/minat-

baca-warga-indonesia-sangat-rendah/ 